\title{
New data on the Miocene stem lagomorph Eurolagus fontannesi, and its northernmost record
}

Łucja Fostowicz-Frelik, Adam Nadachowski, and Magdalena Kowalewska-Groszkowska

Acta Palaeontologica Polonica 57 (1), 2012: 1-20 doi: http://dx.doi.org/10.4202/app.2010.0109

We describe new dental material of Eurolagus fontannesi from the Late Miocene (Early Vallesian, MN9) lignite beds of Bełchatów A (central Poland), which is the northernmost occurrence of this lagomorph. This material considerably increases the sample size of this rare genus and species. We review the systematic position of Eurolagus and argue that it is not an ochotonid, but represents a terminal taxon of an independently evolved stem lineage of Lagomorpha. The enamel of the molars, here studied for the first time, exhibits a relatively thin decussating external and a radial internal layer, and in general resembles the palaeolagine lagomorphs (Palaeolagus) rather than the archaeolagine leporids (Hypolagus) or advanced ochotonids (Ochotona). The dental wear features of Eurolagus fontannesi indicate that the species was a sylvan mixed-feeder. This agrees with the Bełchatów A paleoenvironment, which is best approximated as the kind of mixed mesophytic forest now encountered in the Caucasus, Iran, and India. The extinction of Eurolagus was probably related to the noticeable faunal change following the increased cooling of the European climate during the Late Miocene. The first indicator of this event can be observed in Bełchatów A, marked by the immigration of Microtocricetus and the absence of Neocometes.

Key words: Lagomorpha, Eurolagus, microwear, paleoecology, semihypsodonty, Vallesian, Bełchatów, Poland.

Łucja Fostowicz-Frelik [lfost@twarda.pan.pl], Institute of Paleobiology, Polish Academy of Sciences, Twarda 51/55, PL 00-818 Warsaw, Poland and Division of Paleontology; current address: American Museum of Natural History, Central Park West at 79th Street, New York, NY 10024, USA; Adam Nadachowski [nadachowski@biol.uni.wroc.pl], Department of Paleozoology, Institute of Zoology, University of Wrocław, Sienkiewicza 21, PL 50-335 Wrocław, Poland; Magdalena Kowalewska-Groszkowska [mkowalewska@miiz.waw.pl], Museum and Institute of Zoology, Polish Academy of Sciences, Wilcza 64, PL 00-679 Warsaw, Poland. 
This is an open-access article distributed under the terms of the Creative Commons Attribution License (for details please see creativecommons.org), which permits unrestricted use, distribution, and reproduction in any medium, provided the original author and source are credited.

For Full text $(1,837.2 \mathrm{kB})$ 